\title{
KARAKTERISASI DAERAH DEDEKIND
}

\author{
Elvinus R. Persulessy ${ }^{1}$, Novita Dahoklory² \\ 1,2 Jurusan Matematika FMIPA Universitas Pattimura \\ Jl. Ir. M. Putuhena, Kampus Unpatti, Poka-Ambon, Indonesia \\ e-mail: ${ }^{1}$ richardelvinus@yahoo.com
}

\begin{abstract}
Abstrak
Suatu daerah integral $R$ dengan lapangan hasil bagi $Q(R), R$ dikatakan sebagai Daerah Dedekind jika dan hanya jika $R$ adalah ring Noetherian, tertutup secara integral di $Q(R)$ dan setiap ideal prima yang bukan nol adalah ideal maksimal. Penelitian ini akan dibahas karakteristik Daerah Dedekind dan hubungan antara Daerah Dedekind dan Daerah Ideal Utama dengan tahapan sebagai berikut: mengidentifikasi $R$ yang tertutup secara integral dan ideal fraksional dari $R$, Selanjutnya diberikan karakteristik Daerah Dedekind serta kaitan antara Daerah Dedekind dan Daerah Ideal Utama. Hasil penelitian menunjukkan bahwa jika setiap ideal fraksional di $R$ memiliki invers maka $R$ daerah Dedekind dan setiap Daerah Ideal Utama memenuhi Daerah Dedekind.
\end{abstract}

Kata Kunci: Daerah Dedekind, ideal fraksional, tertutup secara integral.

\section{CHARACTERIZATION OF DEDEKIND DOMAIN}

\begin{abstract}
An integral domain $R$ with quetion field $Q(R)$ is called a Dedekind Domain if and only if $R$ satisfied Noetherian ring, integrally closed over its quetion field $Q(R)$, and every nonzero prime ideal of $R$ is maximal ideal. In this paper, we discuss about the identification of the characteristic of Dedekind Domain and the relation of Dedekind Domain and prinsipal ideal domain by identifying the integrally closed domain and fractional then determine the characteristic of Dedekind Domain. The result proves that if every fractional ideal in $R$ is invertible then $R$ is Dedekind Domain and that every principal ideal domain is a Dedekind Domain.
\end{abstract}

Keywords: Dedekind domain, fractional ideal, integrally closed.

\section{Pendahuluan}

Matematika dibagi dalam berbagai rumpun keilmuan, antara lain Aljabar, Analisis, Matematika Terapan, dan Statistik. Dalam aljabar sendiri terbagi dalam berbagai bidang seperti Aljabar Abstrak, Aljabar Linier, Aljabar Geometri dan sebagainya. Aljabar Abstrak merupakan bidang yang mempelajari struktur aljabar antara lain ruang vektor, modul, grup dan ring. Salah satu konsep aljabar abstrak yang telah dipelajari adalah konsep ring. Ring adalah suatu himpunan tak kosong yang dilengkapi dua operasi biner yaitu penjumlahan $(+)$ dan pergandaan $(\cdot)$ yang memenuhi aksioma-aksioma ring yaitu terhadap operasi penjumlahan merupakan grup abelian, dan terhadap operasi pergandaan merupakan semi grup dan memenuhi sifat distributif kiri dan kanan terhadap operasi penjumlahan dan operasi pergandaan. Selanjutnya ring yang memenuhi sifat komutatif terhadap pergandaan disebut ring komutatif.

Dalam aljabar abstrak, daerah Dedekind merupakan daerah integral dimana setiap ideal tak nolnya dapat difaktorkan menjadi hasil kali dari ideal-ideal prima. Selanjutnya salah satu sifat yang dimiliki oleh ring komutatif secara umum adalah bahwa untuk setiap ideal maksimalnya merupakan ideal prima, sebaliknya belum tentu berlaku. Tetapi dalam daerah Dedekind pada ideal prima yang bukan nol berlaku juga sebaliknya, yaitu untuk setiap ideal prima yang bukan nol adalah ideal maksimal. Daerah Dedekind memiliki banyak karakteristik. Dalam penelitian ini akan dijelaskan karakteristik daerah Dedekind serta kaitan daerah Dedekind dengan daerah ideal utama. 


\section{Tinjauan Pustaka}

Daerah Dedekind diperkenalkan oleh Richard Dedekind pada tahun 1879. Dalam aljabar abstrak, daerah Dedekind merupakan daerah integral dimana setiap ideal tak nolnya dapat difaktorkan menjadi hasil kali dari ideal-ideal prima. Dalam [1], Passman menulis bahwa suatu daerah integral $D$ dengan lapangan hasil bagi $Q$ merupakan daerah Dedekind jika dan hanya jika (i) $D$ memenuhi ring noether, (ii) $D$ tertutup secara integral (Integrally closed), dan (iii) setiap ideal prima tak nolnya merupakan ideal maksimal.

Dasar teori mengenai konsep dasar ring diberikan dalam [2] dan ring komutatif, ring noether, dan ideal fraksional juga mengacu pada [3]. Selanjutnya untuk teori modul mengacu pada [4]. Untuk menjelaskan kaitan daerah Dedekind dan daerah ideal utama diperlukan beberapa definisi dan teorema pendukung yakni definisi daerah ideal utama, definisi Daerah Faktorisasi Tunggal (DFT) serta teorema pendukung yang merujuk pada [5]. Selanjutnya definisi tertutup secara integral dan pembahasan mengenai karakteristik Daerah Dedekind juga mengacu pada [1].

Definisi 1. Suatu ring $(R,+, \cdot)$ adalah suatu himpunan tak kosong yang dilengkapi dengan dua operasi biner yang memenuhi aksioma-aksioma berikut :

i. Terhadap penjumlahan $(R,+)$ merupakan grup abelian.

ii. Terhadap pergandaan $(R, \cdot)$ merupakan semi grup yaitu tertutup dan asosiatif.

iii. Memenuhi sifat distributif kiri dan kanan, yaitu untuk setiap $a, b, c \in R$ berlaku :

a. Distributif Kiri, $a \cdot(b+c)=a \cdot b+b \cdot c$ dan

b. Distributif Kanan $(a+b) \cdot c=a \cdot c+b \cdot c$.

Definisi 2. Diberikan $R$ ring, $R$ dikatakan sebagai ring komutatif (commutative ring) jika operasi pergandaan pada $R$ memenuhi komutatif sedemikian hingga $(\forall a, b \in R) a b=b a$.

Definisi 3. Ring $R$ yang memuat elemen satuan dinamakan sebagai ring dengan elemen satuan (dinotasikan dengan $\left.1_{R}\right)$ pada operasi pergandaan $\left(\exists 1_{R} \in R\right)(\forall a \in R) 1_{R} a=a 1_{R}=a$. Elemen $1_{R}$ disebut elemen satuan (unity element).

Definisi 4. Ring komutatif $R$ yang memuat elemen satuan disebut sebagai ring komutatif dengan elemen satuan.

Definisi 5. Diberikan $R$ ring komutatif dengan elemen satuan, $R$ disebut daerah integral jika $a b=0$, berlaku $a=0$ atau $b=0$, sehingga $R$ tidak memuat pembagi nol.

Definisi 6. Diberikan $R$ ring komutatif dengan elemen satuan, suatu elemen $a \in R$ yang bukan nol disebut unit jika terdapat $b \in R$ sedemikian hingga $b=b a=1_{R}$.

Definisi 7. Jika $R$ daerah integral, maka dapat dibentuk suatu lapangan $Q(R)$ yang memuat semua elemen berbentuk $a b^{-1}$ dimana $a, b \in R$ dengan $\neq 0_{R}, Q(R)$ disebut lapangan hasil bagi (quetion field).

Definisi 8. Misalkan $R$ ring dan $I \subseteq R, I$ disebut ideal dari ring $R$ jika memenuhi :

i. Untuk setiap $a, b \in I$ maka $a-b \in I$.

ii. Untuk setiap $a \in I$ dan $r \in R$, maka ar $\in I$ dan $r a \in I$.

Selanjutnya untuk setiap $r \in R, I r=\{a r \mid a \in I\}$ dengan $I r \subseteq I$ disebut ideal kanan dan $r I=\{r a \mid a \in I\}$ dengan $r I \subseteq I$ disebut ideal kiri.

Definisi 9. Diberikan $(R,+, \cdot)$ suatu ring, Ideal $I$ disebut ideal utama jika $I$ dapat dibangun oleh suatu elemen dalam $R$ yaitu $a \in R$ sedemikian hingga $I=\langle a\rangle$.

Definisi 10. Suatu daerah integral $R$ dinamakan Daerah Ideal Utama jika setiap ideal di $R$ merupakan ideal utama.

Teorema 1. Diberikan $R$ daerah integral, $a, b \in R, a$ membagi $b$ jika dan hanya jika $\langle b\rangle \subseteq\langle a\rangle$.

Definisi 11. Misalkan $R$ suatu ring komutatif dan $I$ suatu ideal dari R. $I$ disebut Ideal Prima jika dalam $R$, jika jika $A B \in I$, maka $A \in I$ atau $B \in I$. 
Definisi 12. Misalkan $R$ suatu ring dan $I$ adalah suatu ideal dari $R$ dengan $I \neq R$. $I$ disebut Ideal Maksimal dari $R$, jika tidak ada ideal dari $R$ yang memuat $I$ selain $I$ dan $R$ sendiri.

Definisi 13. Suatu daerah integral $D$ disebut daerah faktorisasi tunggal atau Unique Factorization Domain (UFD) jika memenuhi :

i. Jika $a \in D, a \neq 0$, maka $a$ dapat ditulis sebagai perkalian sejumlah hingga elemen-elemen tak tereduksi di $D$ yaitu $a=u p_{1} p_{2} \ldots p_{n}$ dengan $p_{i}$ elemen-elemen tak tereduksi $(1 \leq i \leq n)$ dan $u$ unit di $D$.

ii. Jika $a \in D$ dan $a=u p_{1} p_{2} \ldots p_{r}=v q_{1} q_{2} \ldots q_{s}$ dengan masing-masing $p_{i}$ elemen-elemen tak tereduksi dan $u, v$ unit di $D$, maka $r=s$ dan $p_{i}$ berasosiasi dengan $q_{i}$ untuk suatu dan $(1 \leq i \leq r)$ dan $(1 \leq j \leq s)$.

Definisi 14. Diberikan ring komutatif $R$ dengan elemen satuan dan indeterminate $X$.

$$
R[X]=\left\{a_{n} x^{n}+a_{n-1} x^{n-1}+\cdots+a_{1} x^{1}+a_{0} x^{0} \mid a_{i} \in R, n \geq 0\right\}
$$

adalah ring polinomial atas $R$ dengan indeterminate $X$ dimana $n$ adalah bilangan bulat non negatif dan $a_{i}$ adalah elemen dari $R$.

Dari Definisi 14 diketahui bahwa $R[x]$ merupakan himpunan dari semua polinomial dengan koefisiennya ada dalam ring $R$.

Definisi 15. Jika $f(x)$ adalah polinomial berderajat $n$, maka koefisien $a_{n}$ disebut sebagai koefisien utama (leading coefficient) dari $f(x)$. Polinomial $f(x)$ dikatakan sebagai polinomial monik jika koefisien utamanya adalah 1 .

Dari Definisi 15 diketahui bahwa bentuk umum dari polinomial monik yaitu $f(x)=\sum_{i=0}^{n} a_{i}(x)^{i}=$ $x^{n}+a_{n-1} x^{n-1}+\cdots+a_{1} x^{1}+a_{0} x^{0}$, karena koefisien utamanya adalah 1 .

Definisi 16. Diberikan $R$ ring komutatif dengan elemen satuan, $R$ dikatakan memenuhi syarat rantai naik (ascending chain) jika setiap rantai naik dari ideal-ideal :

$$
A_{1} \subseteq A_{2} \subseteq A_{3} \subseteq \cdots \subseteq \cdots,
$$

terdapat suatu bilangan bulat $k$ sedemikian hingga

$$
A_{1} \subseteq A_{2} \subseteq \cdots \subseteq A_{k}=A_{k+1}=A_{k+1}=\cdots
$$

Definisi 17. Diberikan $R$ ring komutatif dengan elemen satuan dikatakan ring Noetherian jika memenuhi kondisi rantai naik pada idealnya.

Definisi 18. Diberikan $R$ ring dengan elemen satuan dan $M$ grup abelian terhadap penjumlahan, serta diberikan pula suatu operasi biner (disebut pergandaan skalar) $: R \times M \rightarrow M$. Himpunan $M$ disebut modul kiri atas ring $R$ jika memenuhi aksioma perkalian skalar yaitu untuk setiap $m_{1}, m_{2}, m \in M$ dan untuk setiap $r_{1}, r_{2}, r \in R$

i. $r \cdot\left(m_{1}+m_{2}\right)=r \cdot m_{1}+r \cdot m_{2}$;

ii. $\left(r_{1}+r_{2}\right) \cdot m=r_{1} \cdot m+r_{2} \cdot m$;

iii. $\left(r_{1} r_{2}\right) \cdot m=r_{1} \cdot\left(r_{2} \cdot m\right)$;

iv. $1_{R} \cdot m=m$, dengan $1_{R}$ merupakan elemen satuan di $R$.

Definisi 19. Diberikan $R$ ring dengan elemen satuan dan $M$ grup abelian terhadap penjumlahan, serta diberikan pula suatu operasi biner (disebut pergandaan skalar) $: M \times R \rightarrow M$. Himpunan $M$ disebut modul kanan atas ring $R$ jika memenuhi aksioma perkalian skalar yaitu untuk setiap $m_{1}, m_{2}, m \in M$ dan untuk setiap $r_{1}, r_{2}, r \in$ $R$

i. $\left(m_{1}+m_{2}\right) \cdot r=m_{1} \cdot r+m_{2} \cdot r$

ii. $m \cdot\left(r_{1}+r_{2}\right)=r_{1} \cdot m+r_{2} \cdot m$;

iii. $m \cdot\left(r_{1} r_{2}\right)=\left(m \cdot r_{1}\right) r_{2}$;

iv. $m \cdot 1_{R}=m$, dengan $1_{R}$ merupakan elemen satuan di $R$.

Definisi 20. Diberikan $R$ ring dengan elemen satuan dan $M$ grup abelian terhadap penjumlahan, jika $M$ adalah modul kiri dan modul kanan maka $M$ disebut bimodul. 
Contoh 1. Diberikan $R$ daerah integral dengan lapangan hasil bagi $Q(R)$, maka $Q(R)$ merupakan bimodul atas $R$.

Definisi 21. Misalkan $M$ modul atas ring $R$ ring dengan elemen satuan dan $N \subseteq M$ maka $N$ adalah submodul dari $M$ jika dan hanya jika :

i. $N$ merupakan subgrup abelian dari $M$;

ii. Operasi pergandaan skalar pada $M$ juga berlaku pada $N$.

Contoh 2. Diberikan $R$ ring dengan elemen satuan adalah modul atas $R$ sendiri. Jika $S$ ideal $R$, maka $S$ merupakan submodul dari $R$.

Definisi 22. Diberikan $R$ suatu ring komutatif, $M$ modul atas $R$, jika $S \subseteq M$, maka himpunan

$$
R\langle S\rangle=\left\{\sum r_{i} s_{i} \mid r_{i} \in R, s_{i} \in S\right\}
$$

dikatakan sebagai submodul yang dibangun secara berhingga.

\section{Hasil dan Pembahasan}

\subsection{Tertutup Secara Integral}

Definisi 23. Diberikan $S$ daerah integral dengan $R$ subring dari $S$, suatu elemen $s \in S$ dikatakan integral atas $R$ jika terdapat polinomial monik $f(x)$ di $R[x]$ berlaku $f(s)=0$.

Secara umum suatu $s \in S$ dikatakan integral atas $R$ jika terdapat polinomial monik $f(x)$ di $R[x]$ yaitu $f(x)=$ $x^{n}+a_{n-1} x^{n-1}+\cdots+a_{1} x^{1}+a_{0} x^{0}$, dimana $s$ merupakan akar dari polinomial $f(x)$, yaitu $\quad f(s)=$ $s^{n}+a_{n-1} s^{n-1}+\cdots+a_{1} s^{1}+a_{0} s^{0}=0$.

Definisi 24. Diberikan daerah integral $R$ dengan lapangan hasil bagi $Q(R) . R$ dikatakan tertutup secara integral jika $s \in Q(R)$ integral atas $R$ maka $s \in R$.

Contoh 3. Daerah integral $\mathbb{Z}$ dengan lapangan hasil bagi $\mathbb{Q}, \mathbb{Z}$ tertutup secara integral.

Penyelesaian. Misalkan suatu $r=\frac{s}{t} \in \mathbb{Q}$ dengan $r \in \mathbb{Q}$ yang integral atas $\mathbb{Z}$ dengan $(s, t)=1$, maka ada suatu polinomial monik $f(x)$ di $\mathbb{Z}[x]$ yaitu

$$
f(x)=\sum_{i=0}^{n} a_{i} x^{i}=a_{0} x^{0}+a_{1} x^{1}+a_{2} x^{2}+\cdots+x^{n}
$$

sedemikian hingga $r=\frac{s}{t} \in \mathbb{Q}$ yang integral atas $\mathbb{Z}$ maka

$$
f\left(\frac{S}{t}\right)=\sum_{i=0}^{n} a_{i}\left(\frac{S}{t}\right)^{i}=a_{0}\left(\frac{S}{t}\right)^{0}+a_{1}\left(\frac{S}{t}\right)^{1}+a_{2}\left(\frac{S}{t}\right)^{2}+\cdots+\left(\frac{S}{t}\right)^{n}
$$

sehingga diperoleh

$$
\begin{aligned}
f\left(\frac{S}{t}\right) & =\sum_{i=0}^{n} a_{i}\left(\frac{S}{t}\right)^{i} \\
0 & =\left(\frac{S}{t}\right)^{n}+\sum_{i=0}^{n-1} a_{i}\left(\frac{S}{t}\right)^{i} \\
\left(\frac{S}{t}\right)^{n} & =-\left(\sum_{i=0}^{n-1} a_{i}\left(\frac{s}{t}\right)^{i}\right) \\
s^{n} & =-\left(\sum_{i=0}^{n-1} a_{i}\left(\frac{S}{t}\right)^{i}\right) t^{n}=-\left(\sum_{i=0}^{n-1} a_{i} s^{i} t^{n-1-i}\right) t
\end{aligned}
$$


dari persamaan diatas diperoleh $t \mid \mathrm{s}^{\mathrm{n}}$, karena $(s, t)=1$ akibatnya $t \mid \mathrm{s}$, sehingga diperoleh $\frac{s}{t} \in \mathbb{Z}$, Jadi $\mathbb{Z}$ tertutup secara integral di $\mathbb{Q}$.

Proposisi 2. Diberikan $R$ suatu daerah integral dengan lapangan hasil bagi $Q(R)$, jika $R$ memenuhi daerah faktorisasi tunggal maka $R$ tertutup secara integral.

Bukti. Misalkan $s$ elemen dari suatu $Q(R)$ dan $s$ integral atas $R$. Misalkan $s=\frac{a}{b}$ dimana $a \in R, b \in R \backslash\{0\}$ dan $a$ dan $b$ saling prima (faktor persekutuan hanya elemen unit) karena $R$ daerah faktorisasi tunggal maka $a$ dan $b$ dapat ditulis sebagai hasil kali elemen-elemen tak tereduksi yaitu

$$
\begin{aligned}
& a=u p_{1} p_{2} \ldots p_{n} \\
& b=u q_{1} q_{2} \ldots q_{m}
\end{aligned}
$$

dimana $u$ merupakan elemen unit di $R$ dan $p_{i}, q_{j}$ merupakan elemen tak tereduksi di $R$, karena $\alpha$ dan $b$ saling prima maka $p_{i} \neq q_{j}$

Selanjutnya diketahui bahwa $s=\frac{a}{b}$ integral atas $R$, maka terdapat suatu polinomial monik

$$
f(x)=s^{n}+r_{n-1} s^{n-1}+\cdots+r_{0}=0
$$

sehingga

$$
\left(\frac{a}{b}\right)^{n}+r_{n-1}\left(\frac{a}{b}\right)^{n-1}+\cdots+r_{0}=0
$$

persamaan di atas dikalikan dengan $b^{n}$ diperoleh

$$
\begin{aligned}
& a^{n}+r_{n-1} b a^{n-1}+\cdots+r_{0} b^{n}=0 \\
& a^{n}=-\left(r_{n-1} b a^{n-1}+\cdots+r_{0} b^{n}\right) \\
& a^{n}=-b\left(r_{n-1} a^{n-1}+\cdots+r_{0} b^{n-1}\right)
\end{aligned}
$$

Sehingga diperoleh $b$ habis membagi $a^{n}$, kondisi ini dapat berlaku jika $b$ merupakan unit, sehingga diperoleh $\frac{a}{b} \in R$.

Terbukti bahwa suatu daerah faktorisasi tunggal memenuhi tertutup secara integral.

\subsection{Ideal Fraksional}

Definisi 25. Diberikan $R$ daerah integral dengan lapangan hasil bagi $Q(R)$, suatu ideal fraksional dari $R$ adalah suatu $R$-submodul yang bukan nol $A$ dari $Q(R)$ sedemikian hingga $d A \subseteq R$, untuk suatu $d \in R$ yang bukan nol.

Dari definisi di atas diketahui bahwa $Q(R)$ merupakan modul atas $R$ dengan ideal fraksionalnya merupakan suatu submodul yang bukan nol dari $Q(R)$. Dari definisi ideal fraksional di atas juga, diketahui bahwa suatu ideal yang bukan nol dalam $R$ juga merupakan suatu ideal fraksional dengan $d=1$.

Contoh 4. Pada daerah integral bilangan bulat $\mathbb{Z}$ dengan lapangan hasil bagi $\mathbb{Q}$, himpunan $\frac{1}{2} \mathbb{Z}$ merupakan ideal fraksional dari $\mathbb{Z}$.

Penyelesaian. Harus dibuktikan terlebih dahulu himpunan $\frac{1}{2} \mathbb{Z}$ merupakan $\mathbb{Z}$-submodul dari $\mathbb{Q}$.

i. himpunan $\frac{1}{2} \mathbb{Z}$ merupakan $\mathbb{Z}$-submodul dari $\mathbb{Q}$

1) $\frac{1}{2} \mathbb{Z}$ merupakan grup abelian terhadap opreasi penjumlahan

2) Operasi pergandaan skalar yang berlaku pada $\mathbb{Q}$ juga berlaku pada $\frac{1}{2} \mathbb{Z}$

a. Ambil sebarang $a \in \mathbb{Z}$ dan $\frac{1}{2} x, \frac{1}{2} y \in \frac{1}{2} \mathbb{Z}$ dimana $x, y \in \mathbb{Z}$

$$
a\left(\frac{1}{2} x+\frac{1}{2} y\right)=a\left(\frac{x+y}{2}\right)=\left(\frac{a(x+y)}{2}\right)=\frac{a x+a y}{2}=\frac{a x}{2}+\frac{a y}{2}
$$


b. Ambil sebarang $a, b \in \mathbb{Z}$ dan $\frac{1}{2} x \in \frac{1}{2} \mathbb{Z}$ dimana $x \in \mathbb{Z}$

$$
(a+b) \frac{1}{2} x=a \frac{1}{2} x+a \frac{1}{2} x=\frac{1}{2} x a+\frac{1}{2} x b
$$

c. Ambil sebarang $a, b \in \mathbb{Z}$ dan $\frac{1}{2} x \in \frac{1}{2} \mathbb{Z}$ dimana $x \in \mathbb{Z}$

$$
(a b) \cdot \frac{1}{2} x=\left(a b \frac{1}{2} x\right)=a\left(b \frac{1}{2} x\right)
$$

d. Ambil sebarang $\frac{1}{2} x \in \frac{1}{2} \mathbb{Z}$

$$
\text { 1. } \frac{1}{2} x=\frac{1}{2} x \cdot 1=\frac{1}{2} x
$$

ii. Terdapat suatu $d \in \mathbb{Z}$ yang bukan nol berlaku $d\left(\frac{1}{2} \mathbb{Z}\right) \subseteq R$ yaitu $\{ \pm 2, \pm 4, \ldots\}$

Dari pembuktian di atas diperoleh $\frac{1}{2} \mathbb{Z}$ merupakan suatu ideal fraksional dari $\mathbb{Z}$.

Teorema 3. Jika $A$ suatu $R$-submodul dari $Q(R)$ yang dibangun secara berhingga maka $A$ merupakan suatu ideal fraksional dari $R$.

Bukti. Misalkan $A$ suatu $R$-submodul dari $Q(R)$ dibangun secara berhingga oleh $q_{1}, q_{2}, \ldots q_{n} \in Q(R)$. A dapat ditulis sebagai

$$
A=q_{1} r_{i}+q_{2} r_{i}+\cdots+q_{n} r_{i}
$$

dengan $r_{i} \in R$ dan $q_{i} \in Q(R)$ maka $q_{i}=\frac{a_{i}}{b_{i}}$, dimana $a_{i} \in R$ dan $b_{i} \in R \backslash\{0\}$

$$
A=\frac{a_{1}}{b_{1}} R+\frac{a_{1}}{b_{2}} R+\cdots+\frac{a_{n}}{b_{n}} R
$$

Jika $\frac{a_{i}}{b_{i}}$. Misalkan $b=b_{1} b_{2} \ldots b_{n}$ maka diperoleh

$$
A=\frac{a_{1}\left(b_{2} \ldots b_{n}\right)}{b} r_{i}+\frac{a_{1}\left(b_{1} b_{3} \ldots b_{n}\right)}{b} r_{i}+\cdots+\frac{a_{n}\left(b_{1} \ldots b_{n-1}\right)}{b} r_{i} .
$$

Persamaan di atas dapat ditulis sebagai

$$
A=\frac{p_{1}}{b} r_{i}+\frac{p_{2}}{b} r_{i}+\cdots+\frac{p_{n}}{b} r_{i}
$$

Maka diperoleh $A$ merupakan suatu ideal fraksional yaitu untuk suatu $b \in R$ yang bukan nol diperoleh $b A \in R$.

Definisi 26. $R$ daerah integral dengan lapangan hasil bagi $Q(R)$ dan $A, B$ ideal-ideal fraksional dari $R$, maka hasil kali $A B$ merupakan himpunan dari penjumlahan berhingga $\sum_{i} a_{i} b_{i}$ dimana $a_{i} \in A, b_{i} \in B$.

Sama seperti perkalian pada ideal biasa di $R$ perkalian dari dua ideal fraksional juga merupakan ideal fraksional, berikut diberikan pembuktiannya dalam teorema berikut.

Teorema 4. $R$ daerah integral dengan lapangan hasil bagi $Q(R)$ dan $A, B$ ideal-ideal fraksional dari $R$, maka hasil kali $A B$ merupakan ideal fraksional.

Bukti. Diketahui $A$ dan $B$ ideal-ideal fraksional dari $R$ maka terdapat $r, s \in R$ yang bukan nol sedemikian hingga

$$
r A \subseteq R
$$

dan

$$
s B \subseteq R .
$$

Jika $r A$ dan $s B$ dikalikan maka diperoleh

$$
(r A)(s B)=(r s) A B \subseteq R
$$


Karena $r s \in R$ bukan nol dan $A B$ submodul yang bukan nol maka diperoleh $A B$ ideal fraksional.

Definisi 27. $R$ daerah integral dengan lapangan hasil bagi $Q(R)$ dan $A$ ideal fraksional dari $R$, maka ideal fraksional $A$ memiliki invers jika terdapat $B$ suatu ideal fraksional dari $R$ sedemikian hingga $A B=R$.

Contoh 5. $\mathbb{Z}$ daerah integral dengan lapangan hasil bagi $\mathbb{Q}$, ideal fraksional $n \mathbb{Z}$ memiliki invers yaitu $\frac{1}{n} \mathbb{Z}$.

Penyelesaian. Diketahui $n \mathbb{Z}$ merupakan suatu ideal fraksional, selanjutnya dapat ditunjukkan bahwa $\frac{1}{n} \mathbb{Z}$ merupakan suatu ideal fraksional dari $\mathbb{Z}$, sesuai dengan Teorema 2 maka $A B$ merupakan suatu ideal fraksional, selanjutnya perkalian dua ideal fraksional $n \mathbb{Z}$ dan $\frac{1}{n} \mathbb{Z}$ diperoleh :

$$
(n \mathbb{Z})\left(\frac{1}{n} \mathbb{Z}\right)=\left(n \frac{1}{n}\right) \mathbb{Z}=1 \cdot \mathbb{Z}=\mathbb{Z}
$$

Sehingga diperoleh $\frac{1}{n} \mathbb{Z}$ merupakan invers dari ideal fraksional $n \mathbb{Z}$.

Teorema 5. Jika $A$ memiliki invers maka $A$ dibangun secara berhingga.

Bukti. Diketahui $A$ memiliki invers, maka terdapat $A^{\prime}$ sedemikian hingga $A A^{\prime}=R$ sehingga terdapat $1 \in A A^{\prime}$ dengan

$$
1=\sum_{i} a_{i} a_{i}{ }^{\prime}=a_{1} a_{1}^{\prime}+a_{2} a_{2}^{\prime}+\cdots+a_{n} a_{n}^{\prime}
$$

untuk suatu $a_{1}, a_{2}, \ldots, a_{n} \in A$ dan $a_{1}{ }^{\prime}, a_{2}{ }^{\prime}, \ldots, a_{n}{ }^{\prime} \in A^{\prime}$. Jika $a \in A$ maka

$$
a=\left(a a_{1}^{\prime}\right) a_{1}+\left(a a_{2}^{\prime}\right) a_{2}+\cdots+\left(a a_{n}^{\prime}\right) a_{n},
$$

dimana setiap $a a_{1}^{\prime} \in R$, sehingga $A$ dibangun secara berhingga oleh $a_{1}, a_{2}, \ldots, a_{n}$ sehingga $A$ dibangun secara berhingga.

\subsection{Daerah Dedekind}

Pada bagian ini akan diberikan karakteristik daerah Dedekind yang mencakup definisi daerah Dedekind, dan teorema dalam daerah Dedekind serta kaitan antara daerah Dedekind dan daerah ideal utama.

Definisi 28. (Passman, 1991) Daerah integral $R$ dengan lapangan hasil bagi $Q(R)$ dikatakan sebagai suatu daerah Dedekind jika memenuhi:

i. $R$ merupakan ring Noetherian.

ii. $R$ tertutup secara integral.

iii. Setiap ideal prima bukan nol dari $R$ adalah ideal maksimal.

Contoh 6. Daerah integral bilangan bulat $\mathbb{Z}$ dengan lapangan hasil bagi $\mathbb{Q}$ merupakan daerah Dedekind.

\section{Penyelesaian.}

(i) $\mathbb{Z}$ ring Noetherian

Diketahui bahwa ideal di $\mathbb{Z}$ berbentuk $n \mathbb{Z}$, yaitu

$$
n \mathbb{Z}=\{n \mathbb{Z} \mid n \in \mathbb{Z}\}
$$

Jika suatu rantai di ideal dalam $\mathbb{Z}$

$$
n \mathbb{Z} \subseteq v_{1} \mathbb{Z} \subseteq v_{2} \mathbb{Z} \subseteq \cdots
$$

Berdasarkan Teorema 1 diketahui bahwa jika $a \mid b$ maka $\langle b\rangle \subseteq\langle a\rangle$, dari kondisi rantai di atas diketahui bahwa $v_{1} \mid n$ dan $v_{1} \mid v_{2}$ dan seterusnya 
Selanjutnya karena $n \in \mathbb{Z}$, maka dapat $n$ difaktorkan sebagai elemen-elemen tak tereduksi, berikut langkah-langkah faktorisasi dari $n$

$$
\begin{aligned}
n & =p_{1} v_{1} \\
& =p_{1}\left(p_{2} v_{2}\right) \\
& =\left(p_{1} v_{2}\left(p_{3} v_{3}\right)\right. \\
& \vdots \\
& =\left(p_{1} p_{2} \ldots p_{r}\right) v_{r}
\end{aligned}
$$

$v_{r}$ merupakan elemen tak tereduksi sehingga

$$
v_{r}=u v
$$

Dimana $u$ merupakan unit dan $v$ berasosiasi dengan $v_{r}$, sehingga $\left\langle v_{r}\right\rangle$ hanya dimuat pada $\mathbb{Z}$ dan $\left\langle v_{r}\right\rangle$ sendiri.

maka kondisi rantai di atas akan stasioner pada $v_{r} \mathbb{Z}$

$$
n \mathbb{Z} \subseteq v_{1} \mathbb{Z} \subseteq v_{2} \mathbb{Z} \subseteq \cdots \subseteq v_{r} \mathbb{Z}
$$

Jadi setiap koleksi ideal pada ring $\mathbb{Z}$ memenuhi kondisi rantai naik, sehingga $\mathbb{Z}$ ring Noetherian

(ii) Pada Contoh 3 telah dijelaskan bahwa $\mathbb{Z}$ tertutup secara integral.

(iii) Setiap ideal prima bukan nol di $\mathbb{Z}$ adalah ideal maksimal.

Akan ditunjukan $\langle p\rangle$ adalah ideal maksimal.

Diketahui bahwa $\mathbb{Z}$ merupakan daerah ideal utama sehingga setiap ideal di $\mathbb{Z}$ berbentuk $n \mathbb{Z}=\langle n\rangle$

Misalkan $\langle p\rangle$ suatu ideal prima utama maka $p$ merupakan suatu elemen prima.

Karena dalam daerah integral berlaku $p$ elemen prima maka $p$ tidak tereduksi sehingga $p$ dapat ditulis sebagai

dimana $u$ elemen unit dan $x$ berasosiasi dengan $p$,

$$
p=u x
$$

Selanjutnya misalkan $\langle p\rangle \subseteq\langle r\rangle$

Karena $R$ daerah ideal utama maka diperoleh $r \mid p$. Sehingga $r$ merupakan salah satu faktor dari $p$, maka $r$ merupakan unit atau berasosiasi dengan $p$, sehingga muncul dua kondisi yaitu

a. Jika $r$ unit maka diperoleh

$$
\langle r\rangle=\mathbb{Z}
$$

b. Jika $r$ berasosiasi dengan $p$, maka $p=u r$ sehingga diperoleh

$$
\langle r\rangle=\langle p\rangle
$$

Dari kondisi (a) dan (b) diperoleh $\langle p\rangle$ merupakan ideal maksimal karena ideal yang memuat $\langle p\rangle$ hanya $\langle p\rangle$ dan $\mathbb{Z}$.

Dari pembuktian (i), (ii), dan (iii) diperoleh $\mathbb{Z}$ merupakan daerah Dedekind.

Untuk menjelaskan kaitan daerah Dedekind dan daerah ideal utama, diberikan proposisi sebagai berikut:

Proposisi 6. Diberikan $R$ daerah ideal utama maka $R$ daerah Dedekind.

Bukti.

(i) Daerah ideal utama memenuhi ring Noetherian

Diketahui suatu kondisi rantai pada $R$

$$
I_{1} \subseteq I_{2} \subseteq I_{3} \subseteq \cdots \subseteq I_{n} \subseteq I_{n+1} \subseteq \cdots
$$

Didefinisikan

$$
I=\bigcup_{i \geq 1} I_{i}
$$

maka diperoleh $I$ ideal di $R$, karena $R$ daerah ideal utama maka $I$ adalah ideal utama yaitu $I=\langle d\rangle, d \in I$, sehingga $d$ dimuat di suatu $I_{i}$, misalkan $I_{n}$, maka diperoleh $I \subseteq I_{n}$. 
Karena $I$ merupakan gabungan dari ideal-ideal $I_{i}$ maka $I_{n} \subseteq I$ sehingga diperoleh $I_{n}=I$.

Berdasarkan rantai ideal di atas maka diperoleh $I_{n} \subseteq I_{n+1} \subseteq I_{n}$ maka $I_{n}=I_{n+1}$.

Terbukti daerah utama adalah ring Noetherian.

(ii) Telah diketahui bahwa suatu daerah ideal utama memenuhi daerah faktorisasi tunggal, sehingga dengan menggunakan Proposisi 2 yaitu Daerah faktorisasi tunggal memenuhi tertutup secara integral diperoleh daerah ideal utama memenuhi tertutup secara integral.

(iii) Setiap ideal prima bukan nol di $R$ merupakan ideal maksimal

Diberikan $R$ suatu daerah ideal utama dan $\langle p\rangle$ suatu ideal prima dari $R$, dimana $p \in R$. Karena $R$ merupakan daerah ideal utama sehingga setiap ideal di $R$ berbentuk $a R=\langle a\rangle$.

Misalkan $\langle p\rangle$ suatu ideal prima maka berdasarkan maka $p$ merupakan suatu elemen prima maka yang bukan nol dari $\mathbb{Z}$, sehingga $p$ tidak tereduksi, karena $R$ daerah ideal utama, maka $p=u x$ dimana $u$ elemen unit dan $x$ berasosiasi dengan $p$. Selanjutnya misalkan $\langle p\rangle \subseteq\langle r\rangle$. Karena $R$ daerah ideal utama maka diperoleh $r \mid p$. Maka $p$ dapat ditulis sebagai $p=a r$. Karena $p$ elemen tak tereduksi maka $p$ hanya memiliki faktor yang berasosiasi dengan $p$ atau suatu unit, sehingga diperoleh $r$ merupakan unit atau berasosiasi dengan $p$, sehingga muncul dua kondisi yaitu

a. Jika $r$ unit maka diperoleh $\langle r\rangle=R$;

b. Jika $r$ unit berasosiasi dengan $p$, maka $p=u r$ sehingga diperoleh $\langle r\rangle=\langle p\rangle$.

Dari kondisi (a) dan (b) diperoleh $\langle p\rangle$ merupakan ideal maksimal karena $\langle p\rangle$ hanya di $\langle p\rangle$ dan $R$.

Dari pembuktian (i), (ii), dan (iii) diperoleh ideal utama merupakan daerah Dedekind.

Teorema 7. Diberikan $R$ daerah integral, setiap ideal fraksional yang bukan nol di $R$ memiliki invers maka $R$ daerah Dedekind.

Bukti. Diketahui $R$ daerah integral, setiap ideal fraksional di $R$ memiliki invers. Akan dibuktikan $R$ daerah Dedekind.

i. $R$ ring Noetherian

Dari Teorema 5, diketahui bahwa Jika $A$ suatu ideal fraksional memiliki invers maka $A$ dibangun secara berhingga, karena diketahui ideal yang bukan nol dalam $R$ juga merupakan ideal fraksional maka diperoleh $R$ ring Noetherian, karena berlaku jika setiap ideal di $R$ dibangun secara berhingga maka $R$ ring Noetherian.

ii. $R$ tertutup secara integral

Misalkan $s \in Q(R)$ integral atas $R$, maka terdapat polinomial monik $f(x)$ di $R[x]$ yaitu

$$
f(x)=x^{n}+a_{n-1} x^{n-1}+\cdots+a_{1} x^{1}+a_{0} x^{0},
$$

dimana $s$ merupakan akar dari polinomial $f(x)$, sehingga

$$
f(s)=s^{n}+a_{n-1} s^{n-1}+\cdots+a_{1} s^{1}+a_{0} s^{0}=0 .
$$

sehingga $s^{n}=-\sum_{i=0}^{n-1} s^{i} r_{i}$ dengan $r_{i} \in R$. Asumsikan himpunan

$$
X=\sum_{i=0}^{n-1} s^{i} r_{i}
$$

Sehingga diperoleh $X$ merupakan suatu submodul yang bukan nol dari $Q(R)$ yang dibangun oleh $\left\{1, s, s^{2}, \ldots s^{n}\right\}$ dan memuat $s$, berdasarkan Teorema 2 maka $X$ adalah suatu ideal fraksional. Dari rumusan $s^{n}$, juga diperoleh $X^{2} \subseteq X$. Karena himpunan $X$ suatu ideal fraksional bukan nol dari $R$, maka $X$ memiliki invers yaitu $X^{-1}$, dengan $X X^{-1}=R$ sehingga diperoleh $X X X^{-1} \subseteq X X^{-1}$ maka $X \subseteq R$. Karena $X$ memuat $s$ sehingga diperoleh $s \in R$ maka berlaku $R$ tertutup secara integral.

iii. Diberikan $P$ suatu ideal prima tak nol dan $I$ ideal sejati dari $R$ dengan $P \subset I$ maka

$$
P \subseteq P I^{-1} \subseteq I I^{-1}=R \text {. }
$$

Selanjutnya $\left(P I^{-1}\right) I \subseteq P$. Karena $P$ ideal prima dan $P \subset I$, maka diperoleh $\left(P I^{-1}\right) \subseteq P$. Oleh karena itu, $P I^{-1}=P$. Selanjutnya dengan mengalikan persamaan tersebut dengan $I P^{-1}$ diperoleh $I=R$. Jadi $P$ ideal maksimal.

Dari pembuktian (i), (ii), dan (iii) diperoleh $R$ memenuhi daerah Dedekind. 


\section{Kesimpulan}

Dari hasil pembahasan, dapat disimpulkan bahwa jika setiap ideal fraksional di $R$ memiliki invers maka $R$ suatu daerah Dedekind dan suatu daerah ideal utama memenuhi daerah Dedekind.

\section{Daftar Pustaka}

[1] D. S. Passman, A Course in Ring Theory, California: Wadsworth \& Brooks Cole, 1991.

[2] V. K. Khana dan S. K. Bhambri, A Course in Abstract Algebra, Jangpura, New Delhi, 1993.

[3] D. S. Dummit dan R. M. Foote, Abstract Algebra, 2nd penyunt., New York: John William Inc., 1999.

[4] T. W. Hungerford, Algebra, New York: Springer Verlag, 1974.

[5] J. J. Watkins, Topics in Commutative Ring Theory, New Jersey: Princeton University Press., 2007.

[6] D. Surowski, Workbook in Higher Algebra, Manhattan: Kansas State University, 2000. 